\title{
ELECTRIC POWER NETWORK FRACTAL AND ITS RELATIONSHIP WITH POWER SYSTEM FAULT
}

\author{
Hui Hou, Aihong Tang, Hualiang Fang, Xiaoling Yang, Zhaoyang Dong
}

Original scientific paper

Electric power system network is with fractal characteristic. It has the basic feature of a complex network: self-similarity. The authors first calculated the fractal dimension values for several electric power grids, including WSCC (Western Systems Coordinating Council) 9 bus system, IEEE14 bus system, IEEE 30 bus system, IEEE 39 bus system, IEEE 118 bus system and IEEE 300 bus system; as well as some real power grids such as China Southern Power Grid (CSPG) $500 \mathrm{kV}$ main power grid, Guangdong province $500 \mathrm{kV}$ main power grid, and Guangdong province $500 \mathrm{kV}$ and $220 \mathrm{kV}$ mixed power grid, etc. Based on the power grid fractal value, a comparison and relationship between the fractal value and power system failure rate is analysed. The basic conclusion is that for the same voltage level, the larger the scale is, the larger fractal value and higher failure rate the power grid will possibly have. For the same scale, the denser the power grid, the larger fractal value and higher failure rate the power grid will probably have. The conclusions provide a new vision on the power system vulnerability status judgment from an interdisciplinary view and lead to a new research direction.

Keywords: complex system; electric power network; failure rate; fractal; power grid

Fraktal mreže električne energije i njegova povezanost s greškom u energetskom sustavu

Izvorni znanstveni članak

Mreža elektro-energetskog sustava ima karakteristike fraktala. Ima osnovnu značajku složene mreže: sličnost samoj sebi. Autori su najprije izračunali vrijednosti fraktalne dimenzije za nekoliko elektro-energetskih rešetki, uključujući sustav 9 sabirnica WSCC (Western Systems Coordinating Council), sustav 14 sabirnica IEEE, sustav 30 sabirnica IEEE, sustav 39 sabirnica IEEE, sustav 118 sabirnica IEEE i sustav 300 sabirnica IEEE, kao i nekoliko stvarnih energetskih rešetki kao što su $500 \mathrm{kV}$ glavne China Southern Power Grid (CSPG), $500 \mathrm{kV}$ glavne energetske rešetke provincije Guangdong te $500 \mathrm{kV}$ i $220 \mathrm{kV}$ miješane energetske rešetke provincije Guangdong, itd. Na temelju fraktalne vrijednosti energetske rešetke analizirana je usporedba i odnos između fraktalne vrijednosti i intenziteta kvarenja energetskog sustava. Osnovni je zaključak da će za isti nivo napona, što je veća skala, energetska rešetka vjerojatno imati veću fraktalnu vrijednost i veći intenzitet kvarenja. Kod iste skale, što je gušća energetska rešetka to će vjerojatno biti veća fraktalna vrijednost i veći intenzitet kvarenja rešetke. Zaključci pružaju novi uvid u prosudbu statusa osjetljivosti energetskog sustava s interdisciplinarnog gledišta te voditi do novih smjerova u istraživanju.

Ključne riječi: elektro-energetska mreža; energetska rešetka; fraktal; intenzitet kvarenja; složeni sustav

\section{Introduction}

The concept of fractal dimension was proposed in 1960s. In 1967, B. B. Mandelbrot published his famous paper titled "How Long Is the Coast of Britain? Statistical Self-similarity and Fractional Dimension" in "Science" and it is one of the first publications on the topic of fractals. Mandelbrot pointed out that a fractal is a shape made of parts similar to the whole in some way [1]. It is a generic term on self-similarity curves that have geometric dimension between 1 and 2 . The characteristics of this kind of bizarre collection cannot be depicted by Euclidean measure but by fractal, which is the proper invariant of self-similarity figures and structures.

For the last decades, the fractal theory has been applied successfully in physics, chemistry, agriculture, materials science, computer science, medical biology, astronomy, meteorology, demographic, economics, art, history, philosophy of seismology and many other fields $[2,3]$.

In power system engineering, the fractal theory is mainly used to analyze the irregular curve of voltage, current and load, etc. However, this paper considers that power network is just like all the other natural fractal curves, and its fractal dimension can be calculated. Some relationship between the power network fractal and its fault rate has also been studied. The conclusion can provide a new vision on the power system vulnerability status judgment from an interdisciplinary view and probably lead to a new research direction in electrical engineering.

\section{Complex network fractal and its application in power system}

Fractal dimension is an index for characterizing fractal patterns or sets by quantifying their complexity as a ratio of the change in detail to the change in scale. Fractal dimensions are used to characterize a broad spectrum of objects ranging from the abstract to practical phenomena, including turbulence, river networks, urban growth, human physiology, medicine, and market trends $[4 \div 6]$.

Several typical characteristics of fractal are listed as follows.

(1) Self-similarity. In mathematics, a self-similar object is exactly or approximately similar to a part of itself. Many objects in the real world, such as coastlines, broccoli, branch, mountain, rivers, cumulus snow forest computer memory space of the Internet, are statistically self-similar: parts of them show the same statistical properties at many scales. Area with the scope of self-similarity is called non-scaling region.

(2) Irregularity. Fractal is completely irregular. In fact it is so irregular that its overall and local characteristics cannot be described in traditional geometrical language.

The fractal theory has also been applied in many areas of power system engineering, mainly in the following aspects $[7 \div 14]$.

(1) Power system load forecast. Power load curve system is a multidimensional nonlinear system. From the 
power load curve it can be easily seen that it has the characteristics of unsmooth and non-differentiable. Based on the concept of fractal dimension, using the method of the SANDBOX, Time Series Method and Box-counting method can analyse the regional power system load characteristics and data respectively [8], [9]. It is found that electric power system load has fractal features. The load changes in both the same region and the different regions have the selfsimilarity fractal characteristics. This method of load forecasting is a new method for power system load analysis and has a certain guiding significance for power system load forecasting area [10].

(2) The power quality disturbance detection and fault diagnosis. [11] used the correlation dimension as a criterion to make fault diagnosis for steam turbine generator set. The paper pointed out that according to different steam turbine generator characteristics, the fractal dimension signal is obviously different. Its size and variation can reflect the irregularity and complexity degree of vibration of turbo-generator set. The paper described the non-stationary signal. So the fractal dimension can be used as identification characteristics of the working state of steam turbine unit and offers a new way for complex mechanical fault diagnosis.

(3) High resistance ground fault diagnosis and analysis. [12] demonstrated the application of fractal theory to the analysis of high impedance fault disorder. It used root mean square value of continuous current values to describe the transient behaviour characteristics of the system. The algorithm is used for high resistance fault pattern recognition and detection. Based on the small data collection technology, it can be used to distinguish power system fault from other transient phenomenon.

(4) Application in power system protective relay area. [13] pointed out that using the fractal grid theory, the current transformer (CT) saturation phenomenon can be detected and identified numerically. Similarly, the grid fractal theory can also be used to distinguish the transformer inrush current from the differential current in transformers with a high sensitivity [14].

The fractal application in power system has all initiated from the point of analyzing the physical processes characteristic curve of the power system so far such as voltage value, current value, load quantity, etc. It is true that most physical characteristics curves of power system such as voltage, current and load all have the characteristics of concavo-convex, not smoothing, rough and random. It is difficult to describe the characteristics with traditional mathematics. Using fractal geometry can make up for the shortage. Fractal geometry recognizes the inherent regularity directly from the abstract complex nonlinear system without simplification.

Although the fractal theories had been applied to a number of areas in power system, no researches have been found on the power grid structure fractal and its application in recent literature. This paper investigates the fractal dimension value of the power system network and the prospect application trend in the power system network planning.

\section{Box-counting algorithm}

Fractal dimension is a quantitative characteristic of fractal. There are a number of ways to define and calculate the fractal dimension in mathematics. Boxcounting Algorithm is one of the most widely used methods for calculating the fractal dimension [15]. The principle is simple and easy to implement. Take a number of boxes with side length as $\varepsilon$ to cover the entire fractal image. Because there are all kinds of fractal internal cavity and crack in the fractal image, some of the boxes will be empty. Count the number of boxes that is not empty, and write the number as $N(\varepsilon)$. Draw the dots of $\ln N(\varepsilon)$ on $\ln \varepsilon$ in the double logarithm coordinate and then find the best fitting curve, probably a straight line. The slope of the straight line is the box dimension of the fractal image. Use the formula expressions as the following.

$$
D=\frac{k \sum\left[\ln \left(\frac{1}{\varepsilon}\right) \times \ln \left(\frac{N}{\varepsilon}\right)\right]-\sum\left[\ln \left(\frac{1}{\varepsilon}\right) \times \ln \left(\frac{N}{\varepsilon}\right)\right]}{k \sum \ln ^{2}\left(\frac{1}{\varepsilon}\right)-\left(\sum \frac{1}{\varepsilon}\right)^{2}},
$$

The box dimension method can conveniently calculate various kinds of graphics box dimension including the natural world, art, as well as engineering fields. In 1982, Shelberg, Moellering, and Lam roughly calculated the fractal dimension of the west coast of Great Britain as $D \approx 1,25$ and fractal dimension of Australian coast as $D \approx 1,13$. Also the fractal dimension of South Africa coast as $D \approx 1,02$ [16]. In 2004, Sang-Hoon Kim calculated the fractal dimension of cauliflower as $D \approx 2,8$ using the Box-counting Algorithm [17]. However, so far no one has calculated the actual power system network fractal dimensions.

\section{Electric power network fractal dimension}

With the box dimension algorithm, the fractal value of power system network can be easily calculated. Using the Netlogo software developed by Center for Connected Learning and Computer Based Modeling Northwestern University, and the Applied Box Counting model [18], the fractal dimension value of any fractal graphics with typical self-similarity characteristics can be easily calculated.

In the electric power system network, the transmission line can be simplified as the line, and power plants as well as the substations as spots. Consider several typical power network models as follows: Western System Coordinating Council (WSCC) 9 bus system, IEEE 14 bus system, IEEE 30 bus system, IEEE 39 bus system, IEEE 118 bus system, IEEE 300 bus system. In addition, some real world power grids are also explored as follows: $500 \mathrm{kV}$ main power grid in Guangdong province China, $500 \mathrm{kV}$ and $220 \mathrm{kV}$ mixed power grid in Guangdong province China, $500 \mathrm{kV}$ main power grid of China Southern Power Grid (CSPG). 




Figure 1 WSCC 9 bus system

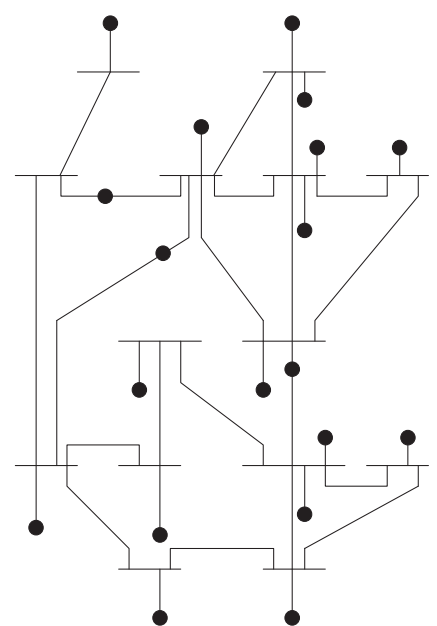

Figure 2 IEEE 14 bus system

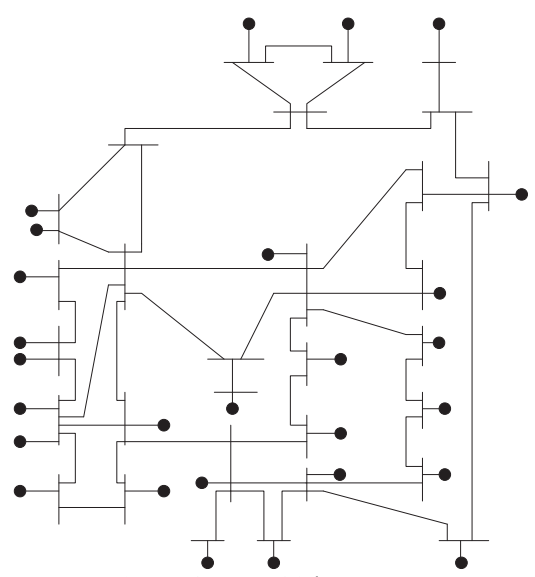

Figure 3 IEEE 30 bus system

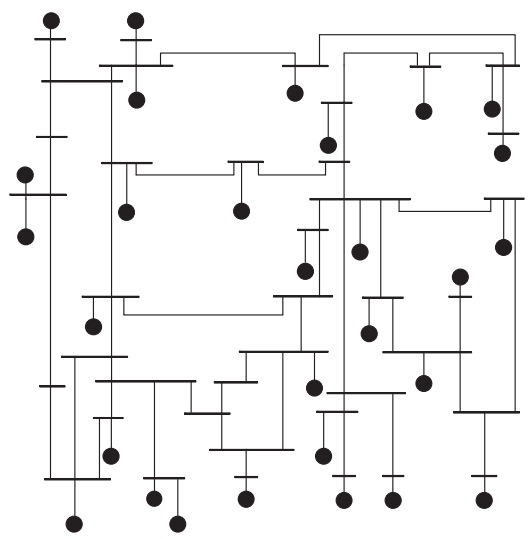

Figure 4 IEEE 39 bus system

The simplified network graphics are shown in Fig. 1 to Fig. 9. Calculate the different power grid fractal dimension value respectively. (In Fig. 9 the larger spots represent the $500 \mathrm{kV}$ power plants and substations whereas the smaller spots represent the $220 \mathrm{kV}$ power plants and substations.) The actual fractal result is a mean value of 10 times calculation.



Figure 5 IEEE 118 bus system
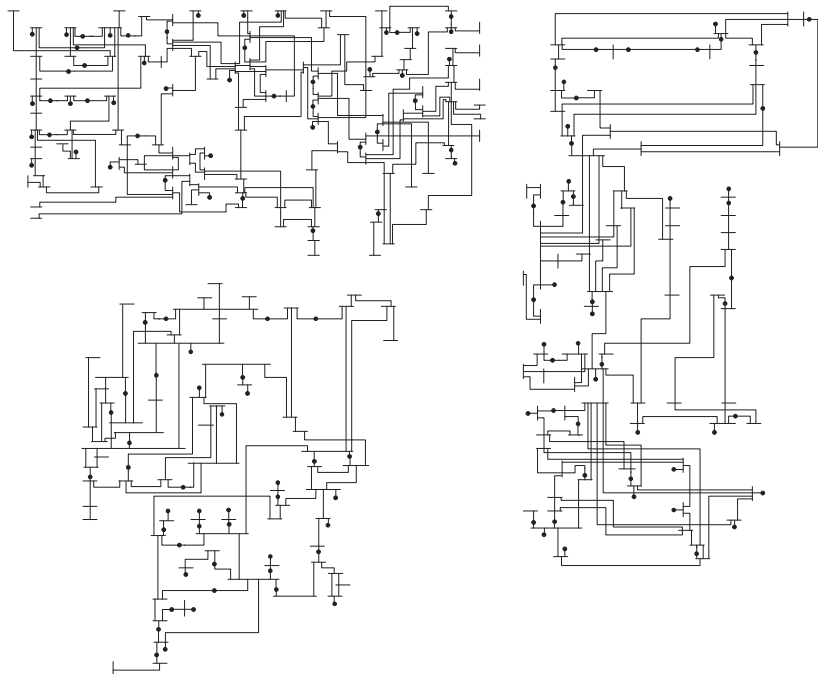

Figure 6 IEEE 300 bus system

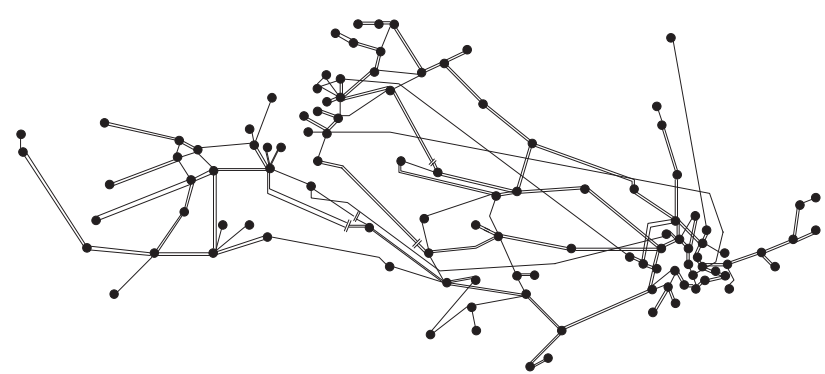

Figure $7500 \mathrm{kV}$ main power grid of China Southern Power Grid (CSPG)

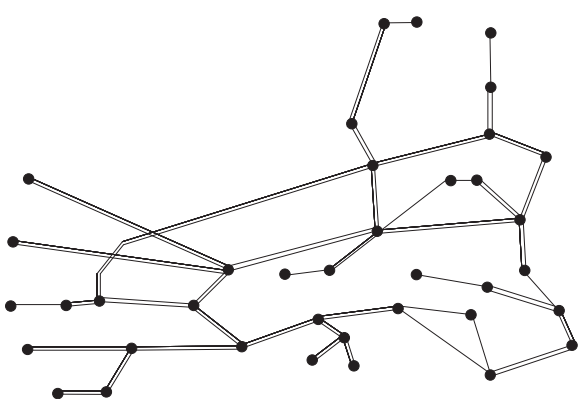

Figure $8500 \mathrm{kV}$ main power grid in Guangdong province China 


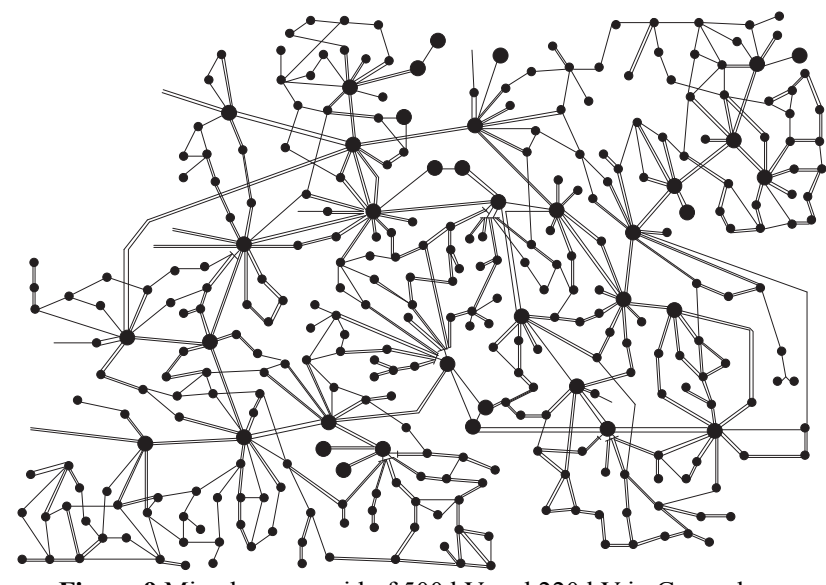

Figure 9 Mixed power grid of $500 \mathrm{kV}$ and $220 \mathrm{kV}$ in Guangdong province China

The above power grid fractal value is listed in Tab. 1.

Table 1 Electric power network fractal dimension list

\begin{tabular}{|l|c|}
\hline \multicolumn{1}{|c|}{} & $\begin{array}{c}\text { Fractal } \\
\text { dimension }\end{array}$ \\
\hline WSCC 9 bus system & 1,15627131 \\
\hline IEEE 14 bus system & 1,23904486 \\
\hline IEEE 30 bus system & 1,25691499 \\
\hline IEEE 39 bus system & 1,32100366 \\
\hline IEEE 118 bus system & 1,44834481 \\
\hline IEEE 300 bus system & 1,55717918 \\
\hline $\begin{array}{l}500 \mathrm{kV} \text { main power grid in Guangdong } \\
\text { province China }\end{array}$ & 1,31550489 \\
\hline $\begin{array}{l}\text { Mixed power grid of 500 kV and 220 kV in } \\
\text { Guangdong province China }\end{array}$ & 1,60933522 \\
\hline $\begin{array}{l}500 \mathrm{kV} \text { main power grid of China Southern } \\
\text { Power Grid (CSPG) }\end{array}$ & 1,49804677 \\
\hline
\end{tabular}

Some preliminary conclusions can be drawn from Tab. 1.

(1) Electric power network has fractal characteristics.

(2) Electricity networks fractal value can be calculated. According to the different intensity, the fractal dimension value varies from 1 to 2 .

(3) For the same voltage level, the larger scale is the power system, the larger is the fractal dimension value. Comparing the Guangdong province power grid and China Southern Power Grid (CSPP) fractal value of $500 \mathrm{kV}$ networks, it can be seen that CSPG fractal value is bigger and its scale is larger.

(4) With the same power grid scale, the more compact is the power network, the larger is the fractal dimension value. Comparing the Guangdong province $500 \mathrm{kV}$ main power grid and the mixed $500 \mathrm{kV}$ and $220 \mathrm{kV}$ Guangdong province power networks, it can be seen that the mixed network with $220 \mathrm{kV}$ grid's fractal value is bigger and the network is much more intensive.

\section{Discussion on the relationship between electric power system fractal and fault}

From what has been elaborated above, it is known that the electric power network has fractal characteristics. Furthermore, this paper holds the opinion that there is some relationship between the power system accident probability and its fractal value. Comparing the
Guangdong province power grid and CSPG failure probability statistics and their fractal dimension, some preliminary conclusion can be drawn: the larger the electric power network fractal dimension, the greater the opportunity that power system fault may occur.

CSPG consists of 5 provinces' power networks including Guangdong, Guangxi, Yunnan, Guizhou and Hainan provinces and regions. It is operated by China Southern Power Grid Co., Ltd. The service area is about 1 million square kilometres, with a population of 230 million. The main power grid structure is made of the 500 $\mathrm{kV}$ transmission lines and the main supporting power grid structure is made of $220 \mathrm{kV}$ power transmission lines. The electric power network graphics with geographical background is shown in Fig. 10 (until the end of 2009). $\mathrm{Up}$ to 2009 , there were $153500 \mathrm{kV}$ power transmission lines, which made up a total of $15771.1 \mathrm{~km}$ transmission lines. For the $220 \mathrm{kV}$ power transmission power grid, there were $1479220 \mathrm{kV}$ power transmission lines in CSPG until the end of 2009. It made up to a total length of $47235 \mathrm{~km}$ in all.

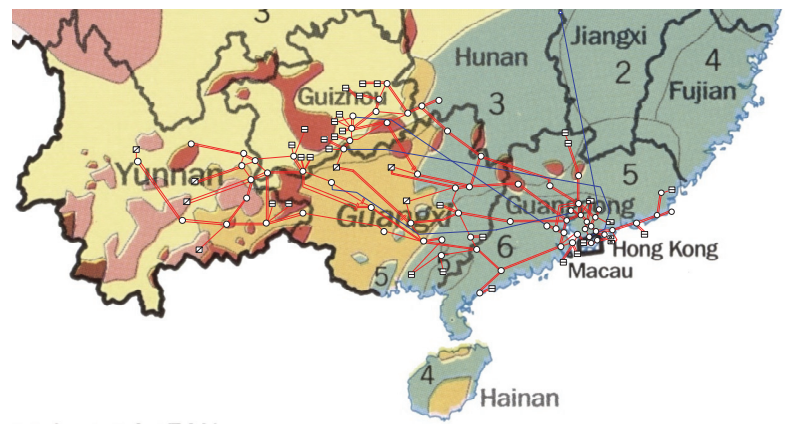

Figure 10 CSPG power grid geographical diagram (Until the end of 2009)

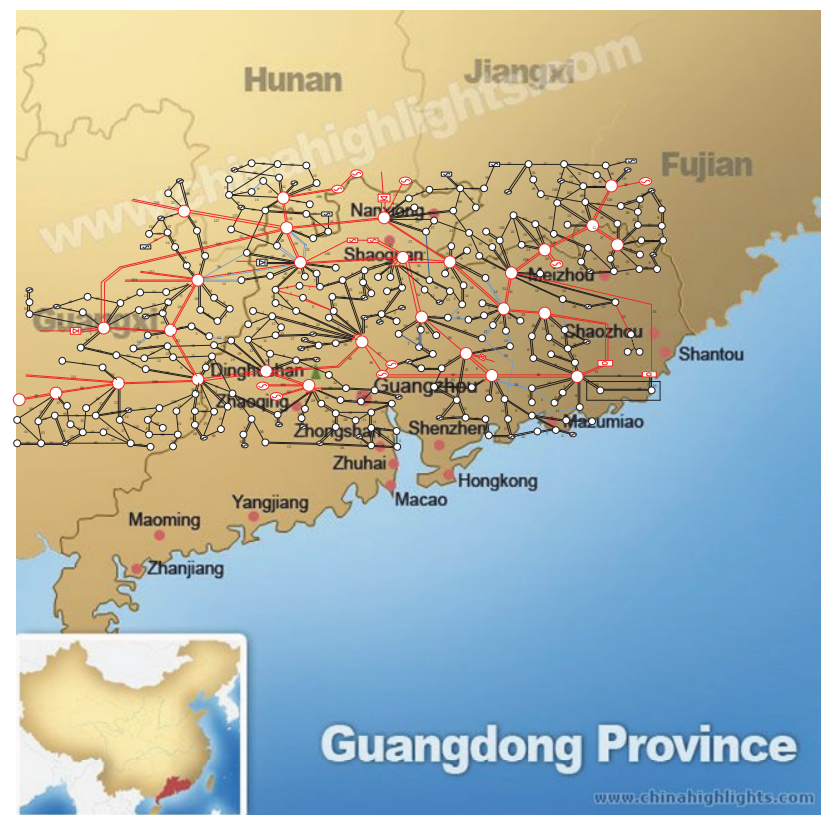

Figure 11Guangdong province power grid geographical diagram (Until the end of 2009)

Among the CSPG, Guangdong province power grid is currently the largest and most complex, even the largest and most complex provincial power grid in the whole China. It occupies an important role of CSPG due to its significant social and economic status of Guangdong 
province. Guangdong province power grid is a typical large receiver-side network of CSPG long-distance, largecapacity, and ultra-high-voltage power network. It is probably the world's most complex receiving side power network; therefore it is especially significant to ensure the security and stability of the provincial power grid. The geographical location of the Guangdong power grid in the whole CSPP can be seen in Fig. 10. The red line represents $500 \mathrm{kVAC}$ line and blue line is for $800 \mathrm{kVDC}$ lines.

Guangdong province power grid geographical network is shown in Fig. 11. The red line represents 500 $\mathrm{kV}$ main power transmission line and blackline represents $220 \mathrm{kV}$ power transmission line.

According to the statistic data, the average Forced Outage Rate of CSPG $500 \mathrm{kV}$ power transmission line is 0,123 times per hundred kilometres a year, whereas the average Forced Outage Rate in $500 \mathrm{kV}$ Guangdong province power grid is 0,021 times per hundred kilometers a year. A list of the related fault data is shown in Tab. 2.

Similarly the statistic data of Guangdong province $500 \mathrm{kV}$ main power grid and mixed power grid of $500 \mathrm{kV}$ and $220 \mathrm{kV}$ power grid Lightning Trip-out Rate, Pollution
Flashover Fault Rate, Forced Outage Rate and the Availability Coefficient is shown in Tab. 3 .

The following conclusions can be inferred from Tabs.

2 and 3 :

(1) For the same voltage level, the larger scale is the power system which has the bigger fractal dimension, the higher the failure rate. For example, the fractal dimension of CSPG $500 \mathrm{kV}$ power grid is larger than the Guangdong province $500 \mathrm{kV}$ power grid. Therefore the overall failure rate of CSPG (Average Unplanned Outage Factor) is a bit higher.

(2) For the same power grid scale, the more compact is the power network, the bigger is the fractal dimension and the higher is the failure rate. Take the Guangdong province power grid for example, the fractal dimension of the mixed $500 \mathrm{kV}$ and $220 \mathrm{kV}$ power grid is larger than the $500 \mathrm{kV}$ main power grid. Therefore the overall failure rate of the mixed power grid (Average Unplanned Outage Factor) is a little higher.

It is indicated that the vulnerability status of power grid can be preliminarily assumed according to the grid fractal dimension.

Table $2500 \mathrm{kV}$ power transmission line of CSPG and Guangdong province stability condition

\begin{tabular}{|l|c|c|}
\hline \multicolumn{1}{|c|}{ Item } & $\begin{array}{c}\text { Guangdong province power } \\
\text { grid (500 kV) }\end{array}$ & CSPG (500 kV) \\
\hline Lightning Trip-out Rate (times per hundred kilometres a year) & 0,26 & 0,273 \\
\hline Pollution Flashover Fault Rate (times per hundred kilometres a year) & 0 & 0,010 \\
\hline Forced Outage Rate (times per hundred kilometres a year) & 0,021 & 0,123 \\
\hline Average Unplanned Outage Factor (\%) & 0,492 & 0,865 \\
\hline Fractal Dimension & 1,31550489 & 1,49804677 \\
\hline
\end{tabular}

Table 3 Guangdong province $500 \mathrm{kV}$ power transmission line and mixed power grid of $500 \mathrm{kV}$ and $220 \mathrm{kV}$ stability condition

\begin{tabular}{|l|c|c|}
\hline \multicolumn{1}{|c|}{ Item } & $\begin{array}{c}\text { Mixed power grid } \\
(500 \mathrm{kV} \text { and } 220 \mathrm{kV})\end{array}$ & 0,36 \\
\hline Lightning Trip-out Rate (times per hundred kilometres a year) & 0 & $0,300 \mathrm{kV}$ \\
\hline Pollution Flashover Fault Rate (times per hundred kilometres a year) & 0,159 & 0,26 \\
\hline Forced Outage Rate (times per hundred kilometres a year) & 0,542 \\
\hline Average Unplanned Outage Factor (\%) & 1,60933522 & 0,492 \\
\hline Fractal Dimension & 1,31550489 & \\
\hline
\end{tabular}

\section{Conclusion}

Complex electric power network has the basic feature of fractal: self-similarity. The paper calculated the fractal dimension of several electric power networks, including the ideal model power grid such as WSCC 9 bus system, IEEE14 bus system, IEEE 30 bus system, IEEE 39 bus system, IEEE 118 bus system and IEEE 300 bus system as well as some real power grids such as China Southern Power Grid (CSPG) 500 kV main grid, Guangdong province $500 \mathrm{kV}$ power grid, and Guangdong province $500 \mathrm{kV}$ and $220 \mathrm{kV}$ mixed power grid, etc.

The basic conclusion is that the power grid fractal dimension value can be calculated as many other complex networks in the natural world. The fractal dimension of the power grid is related to its density as well as the power network scale. Generally speaking, the denser the power grid is the larger fractal dimension it gets for the same scale power grid. And the vaster the scale is the larger fractal dimension it has for the same density. It is also conjectured that the fractal dimension and the power grid failure rate have some close relationship. It is inferred in this paper that the higher fractal dimension value may indicate a higher failure rate for the power system. This conclusion can provide a new vision on the judgment of the power system health state from an interdisciplinary view and lead to a new research direction.

\section{Acknowledgements}

This work was supported by the National Natural Science Foundation of China (Grant Nos. 51107047) and the Fundamental Research Funds for the Central Universities (WUT: 2013-IV-072).

\section{References}

[1] Mandelbrot, B. B. How Long Is the Coast of Britain? Statistical self-similarity and fractional dimension. // Science. 156, 3775(1967), pp. 636-638. DOl: 10.1126/science. 156.3775 .636 
[2] Zhang, Jizhong. Fractal. / Beijing: Tsinghua University Press, 2011.

[3] Zhu, Hua; Ji, Cuicui. Fractal theory and its applications. Beijing: Science Press, 2011.

[4] Pentland, A. P. Fractal-based description of natural scenes. // IEEE transactions on pattern analysis and machine intelligence. 6, 6(1984), pp. 661-674. DOl: 10.1109/TPAMI.1984.4767591

[5] Castillo, O.; Melin, P. Hybrid intelligent systems for time series prediction using neural networks, fuzzy logic, and fractal theory. // IEEE Transactions on Neural Networks. 13, 6(2002), pp. 1395-1408. DOI: 10.1109/TNN.2002.804316

[6] Jacquin, A. E. Fractal image coding: a review. Proceedings of the IEEE, 81, 10(1993), pp. 1451-1465. DOI: $10.1109 / 5.241507$

[7] Ortjohann, E.; Wirasanti, P.; Schmelter, A.; Saffour, H.; Hoppe, M.; Morton, D. Cluster fractal model - A flexible network model for future power systems. // 2013 International Conference on Clean Electrical Power (ICCEP), June 2013, pp. 293-297. DOI: 10.1109/ICCEP.2013.6587004

[8] Thorp, J. S.; Naqavi, S. A. Load flow fractals. // Proceedings of the $28^{\text {th }}$ IEEE Conference on 1989 Decision and Control, 1989, vol. 2, pp. 1822-1827. DOl: 10.1109/CDC.1989.70472

[9] Thorp, J. S.; Naqavi, S. A.; Chiang, N. D. More load flow fractals. // Proceedings of the $29^{\text {th }}$ IEEE Conference on Decision and Control, 1990, vol. 6, pp. 3028-3030. DOI: 10.1109/CDC.1990.203339

[10] Chunsheng, Liu; Degen, Li. The Chaos and Fractal Characteristics and Predication of Shearer Load Power. // 2010 International Conference on Electrical and Control Engineering (ICECE), June 2010, pp. 5696-5699.

[11] Huang, Shyh-Jier; Lin, Jeu-Min. Application of box counting method based fractal geometry technique for disturbance detection in power systems. // IEEE Power Engineering Society General Meeting, Conference Proceedings, 2003, vol. 3, pp. 1604-1608.

[12] Mamishev, A. V.; Russell Carl, D.; Benner, L. Analysis of High Impedance Faults Using Fractal Techniques. // IEEE Transactions on Power Systems. 11, 1(1996), pp. 435-440. DOI: $10.1109 / 59.486130$

[13] Ma, Jing; Wang, Zengping. Application of Grille Fractal in Identification of Current Transformer Saturation. // Power System Technology. 31, 14(2007), pp. 84-88.

[14] Wang, Zengping; Ma, Jing. A Novel Method to Identify Inrush Current Based on Grille Fractal. // Power System Technology. 31, 11(2007), pp. 63-68.

[15] Boshoff, H. F. V. A fast box counting algorithm for determining the fractal dimension of sampled continuous functions. // Proceedings of the 1992 South African Symposium on Communications and Signal Processing, 1992. COMSIG 1992. pp. 43-48. DOl: 10.1109/COMSIG.1992.274315

[16] Shelberg, M.; Moellering, H.; Lam, N. Calculating the Fractal Dimensions of Empirical Cartographic Curves. // Proceedings of the Fifth International Symposium on Computer-Assisted Cartography (AUTO-CARTO 5), 1982, pp. 481-490.

[17] Sang-Hoon, Kim. Fractal structure of a white cauliflower. // Journal of the Korean Physical Society. 46, 2(2005), pp. 474-477.

[18] Applied Box Counting model, Complexity Explorer project, http://complexityexplorer.org.

\section{Authors' addresses}

\section{Hui Hou}

School of Automation,

Wuhan University of Technology,

430070 Wuhan, China

E-mail: houhui@whut.edu.cn

\section{Aihong Tang}

School of Automation,

Wuhan University of Technology,

430070 Wuhan, China

\section{Hualiang Fang}

School of Electrical Engineering,

Wuhan University,

430072 Wuhan, China

\section{Xiaoling Yang}

College of Science,

Hubei University of Technology,

430068 Wuhan, China

\section{Zhaoyang Dong}

School of Electrical \& Information Engineering, The University of Sydney,

2008 Sydney, NSW Australia 